\title{
BEYOND KEYNES AND THE CLASSICS. OUTLINE OF THE GOODS SIDE/MONEY SIDE MODEL OF THE BUSINESS CYCLE AND MACROECONOMIC CONFIGURATIONS
}

\author{
ANTONY P. MUELLER*
}

Fecha de recepción: 26 de mayo de 2014.

Fecha de aceptación: 8 de octubre de 2014.

Resumen: Este trabajo presenta el modelo lado del mercado de bienes/lado del mercado de dinero (GSMS) como una nueva forma de análisis macroeconómico. El modelo GSMS va más allá del keynesianismo, ya que hace una clara distinción entre el lado de los bienes y el lado del dinero y, por tanto, evita la ausencia de diferenciación entre los valores nominales y reales que vienen con el gasto en los modelos de demanda agregada. El modelo GSMS trasciende la macroeconomía clásica en sus versiones tradicional y moderna, ya que restituye al dinero un rol activo en la economía. A diferencia del monetarismo, el concepto monetario clave del modelo GSMS es la «liquidez macroeconómica», que incluye la velocidad de circulación. El presente artículo presenta las características básicas del modelo y muestra su uso mediante el análisis de configuraciones macroeconómicas, el ciclo económico y el crecimiento económico. El documento incluye un apéndice con una evaluación de configuraciones macroeconómicas a la luz del modelo GSMS.

Palabras clave: Modelo Macroeconómico GSMS, Política Monetaria, Crecimiento Económico, Teoría Austriaca del Ciclo Económico.

Clasificación JEL: A23, E32, E52.

* Professor of Economics, Federal University of Sergipe (UFS), Brazil. e-mail: antonymueller@gmail.com - phone: (55) 79.9601.3131. Address: Universidade Federal de Sergipe (UFS), Departamento de Economia, CCSA, Cidade Universitária, CEP 49100-000-SE, SÃO Cristóvão, Sergipe, Brazil. 
Abstract: This paper presents the goods side/money side (GSMS) model as a novel way of macroeconomic analysis. The GSMS model goes beyond Keynesianism as it makes a sharp distinction between the goods side and the money side and thus avoids the indistinctness between real nominal values that come with spending in aggregate demand models. The GSMS model transcends classical macroeconomics in its traditional and modern versions as it reinstates money as an active factor in the economy. Different from monetarism, the key monetary concept of the GSMS model is «macroeconomic liquidity», which includes velocity of circulation. The present paper presents the basic features of the model and shows its use by analyzing macroeconomic configurations, the business cycle, and economic growth. The paper includes an appendix with an evaluation of macroeconomic configurations in the light of the GSMS model.

Key words: GSMS Macroeconomic Model, Monetary Policy, Economic Growth, Austrian Theory of the Business Cycle (ATB).

JEL Classification: A23, E32, E52.

\section{I \\ INTRODUCTION}

Uneasiness with conventional macroeconomics has been rampant long before the current crisis. The financial crisis of 2008 only highlighted once again the frustration with the state of macroeconomics. The ambiguities of ISLM model have already plagued its originator (Hicks 1980/81). Its extension to the aggregate supply and demand model (AS/AD) has not removed the inconsistency of the standard model (Colander 1995). Despite the deficiencies of ISLM-AS model, it continues to serve as the foremost workhorse of macroeconomic analysis both inside and outside of academia. The reason is mainly the lack of an alternative model. There is need of a model that is simple enough for the classroom, yet also sufficiently sophisticated for advanced studies and empirical investigation.

The goods side/money side (GSMS) model provides a vehicle that applies a sharp distinction between monetary and real variables and avoids the vagueness concerning the real and nominal effects 
that come with the concepts of «spending» or «aggregate demand». The GSMS model goes beyond monetarism in its use of the equation of exchange. The key function of this macroeconomic model is to show the links among the main parts of the economy. As such, the GSMS model serves as a guide for teaching and research and offers a framework for the critical discussion of economic policy concepts.

II OUTLINE OF THE GSMS MODEL

The quantity theory of money forms the basis of the present approach. This theory goes back beyond Fisher (1911) Friedman (1956), Hume (1752) and the school of Salamanca (Soto 2012) to the $16^{\text {th }}$ century (Copernicus 1526). Over time, the quantity theory of money has experienced its own cycle with highs, downs and persistent comebacks, particularly after when declared as dead. The quantity theory relates money $(\mathrm{M})$ to national income $(\mathrm{Y})$ and transactions $(\mathrm{T})$ and links these variables with the concept of velocity of circulation (V) or cash balance (k).

In distinction to the Chicago/Fisher transaction version

$$
M \times V=P \times T
$$

and the Cambridge cash balance income version

$$
M=k P Y r
$$

Evans and Thorpe (2013) identify

$$
M=k P T
$$

as the Austrian version as found in the writings of Ludwig von Mises (1912/1971), while Howden (2013) redefines the quantity theory of money more narrowly as «monetary exchange theorem of velocity».

For the approach that we present here by following Hayek (Hayek 1933/1975, Hayek 1983, p. 100), the model makes the 
fundamental distinction between the "goods side» (GS) and the «money side» of the economy. As such, the basic equation for the GS/MS model becomes

$$
\frac{M V}{P}=Q
$$

The GSMS model distinguishes between the "goods side» (GS) and the "money side» (MS) of the economy based on a reformulation of the equation of exchange to separate the monetary variables from the variables for real production, so that the «monetary side» $\left(\frac{M V}{P}\right)$ emerges in distinction from the «goods side» $(Q)$.

With a fixed money supply $(M)$ and a constant velocity $(V)$, the relationship between prices $(P)$ and product $(Q)$ forms a hyperbola as

$$
f(q)=\frac{1}{p}
$$

In its graphical representation (curve ML in figure 1), the stock of money in circulation represents macroeconomic liquidity $(M L)$ and is composed of money as a means of payments $(M)$ multiplied by its income velocity (V). In the GSMS model, «money» is not identical with the so-called «true money supply» of Austrian economics (Salerno 1987) but derives its macroeconomic effects in terms of "macroeconomic liquidity» $(M L)$ to represent the supply of money as a medium of exchange as it includes velocity of circulation. As such, macroeconomic liquidity reflects the actual use of money in the economy.

Different from the Garrison model (Garrison 2000), the goods side in the GSMS model shows the natural production frontier $(N P F)$, which represents the normal or regular output at the given state of the factors of production, while the cyclical production frontier $(C P F)$ shows current output in terms of capacity utilization or degrees of scarcities. The more current production moves beyond the natural production frontier and the more it approaches maximum output at the absolute production frontier $(A B S)$, the more scarcity makes itself manifest. Opportunity costs, or, in 


\section{FIGURE 1}

STANDARD GOODS SIDE/MONEY SIDE (GS/MS) MODEL

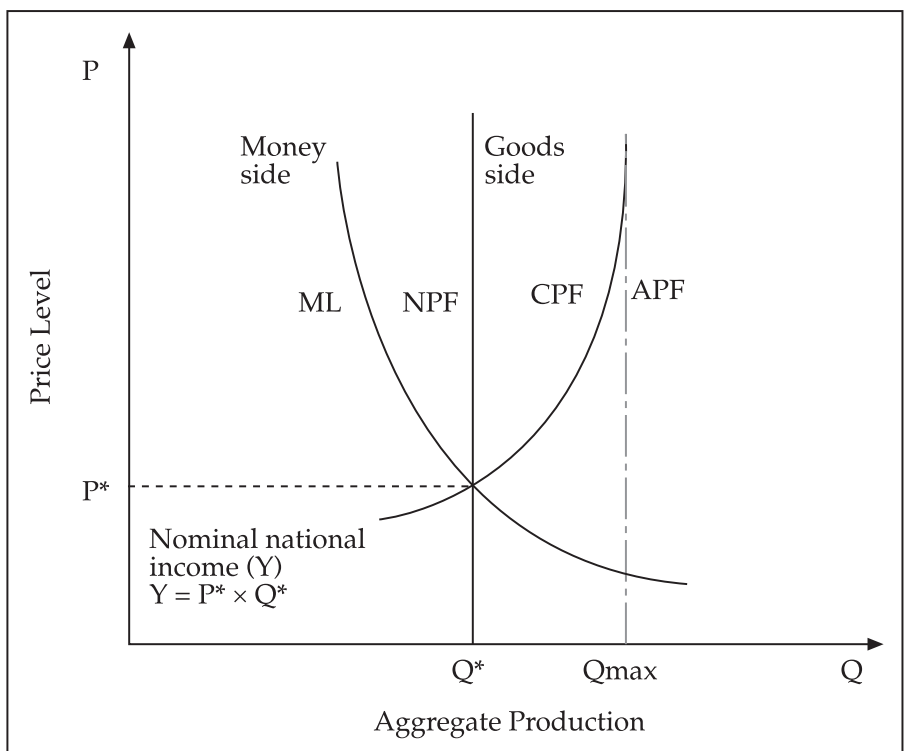

monetary terms, cost prices will augment as the use of current capacity intensifies.

Given that nominal national income $(Y)$ is equal to real production $(Q)$ multiplied by the price level $(P)$, nominal income is the rectangle of the area with the price level and production as its sides. In order to capture nominal national income, the basic model experiences an extension in the form of

$$
M \times V=Q \times P=Y
$$

The extension of the equation by the components of expenditures for consumption $(C)$, investment $(I)$ and government $(G)$ and the external sector opens the black of box of Keynesian «expenditures» and reveals how the standard Keynesian analysis relates to the money side and the goods side of the economy.

$$
\begin{gathered}
Q \times P=Y=C+I+G=P_{C} \times Q_{C}+P_{I} \times Q_{I}+ \\
P_{G} \times Q_{G}+P_{E X} \times Q_{E X}-P_{I M} \times Q_{I M}
\end{gathered}
$$


Likewise, the left side of the basic equation extends to include the sources of liquidity. Macroeconomic liquidity $(M L)$ in the money side of the equation is the result of the monetary base $(M B)$ multiplied by the financial market or banking multiplier $\left(m_{b}\right)$ and the velocity of circulation $(V)$.

$$
M L=M B \times m_{b} \times V
$$

At this stage, the macroeconomic story to tell includes taking account of money, prices and goods that begins with the monetary base and continues with the structure of production. The following equation forms the basis of the analysis of the main macroeconomic variables and their interaction.

$$
\begin{gathered}
B M \times m_{b} \times V=Q \times P=Y=C+I+G= \\
P_{C} \times Q_{C}+P_{I} \times Q_{1}+P_{G} \times Q_{G} \ldots
\end{gathered}
$$

In terms of actors and decisions, the equation contains, beginning at the left and moving to the right, the central bank, which decides on the monetary base, the actors in the financial market, which determine the banking multiplier, and all those economic agents, which decide about cash holdings. At the right side of the equation, the black box of overall production $(Q)$, price level $(P)$ and nominal national income $(Y)$, opens up in terms of relative prices, such as $\mathrm{P}_{\mathrm{C}} / \mathrm{P}_{\mathrm{I}}$ or $\mathrm{P}_{\mathrm{I}} / \mathrm{P}_{\mathrm{Q}}$, at the level of intermediate aggregation. The variation of the scope to lesser degrees of aggregation would lead to the analysis of the structure of production.

The GSMS model makes a distinction between a «natural» and a «cyclical» production frontier (NPF and CPF respectively in figure 1). The distinction between the normal or regular course of affairs and exceptional business activity either beyond or below this level is fundamental to the conduct of a firm. The more economic activity approaches the limits of capacity, the more costs will rise as the result of increasing scarcity, and the more it will be necessary to obtain higher prices in order to maintain profitability. Likewise, when activity falls below its normal level, unused capacity exist and competition drives down prices. Different from the cyclical production frontier $(C P F)$, which indicates the variation 
of current production in relation to the price level, the natural production frontier (NPF) is independent of the price level and shifts according to changes of the quantity and quality of the factors of production.

III

DYNAMICS OF THE GSMS MODEL

The GSMS model consists of the money side (MS), and the goods side (GS) with the differentiation between the natural production frontier (NPF), the absolute production frontier (APF), and the cyclical production frontier $(C P F)$.

The dynamic version of the equation of exchange reads as:

$$
g_{M}+g_{V}=g_{Q}+\pi
$$

Given that macroeconomic liquidity $(M L)$ is composed of money multiplied by its velocity, the equation becomes

$$
\pi=g_{M L}-g_{Q}
$$

In this reduced form, price changes result from the relation between the variation of liquidity and of real economic growth. Applying the determinants elaborated above, the extended equation for price inflation becomes:

$$
\pi=\left(g_{M B}+g_{m b}+g_{v}\right)-\left(g_{Q n}+g_{Q c}\right)
$$

For price stability with an inflation rate of zero $(\pi=0)$, the condition is:

$$
\left(g_{M B}+g_{m b}+g_{v}\right)=\left(g_{Q n}+g_{Q c}\right)
$$

Given that the current the rate of unemployment $\left(u_{t}\right)$ varies inverse to economic expansion, cyclical unemployment is a function of cyclical economic activity $\left(g_{Q c}\right)$. In contrast, natural economic growth (shift of the NPF-curve to the right) comes with steady 
employment or an employment rate that remains at its natural level $\left(u_{n}\right)$ so that the natural unemployment rate $\left(u_{n}\right)$ coincides with the natural production frontier $(N P F)$. Finally, nominal national income $(Y)$ is the product of real production and the price level, or, specified by the model, its growth rate $\left(g_{Y}\right)$ is:

$$
g_{Y}=g_{Q}+\pi=g_{Q n}+g_{Q c}+\pi
$$

These equations provide the tools to compose a table of macroeconomic constellations composed of the variables that show up in the set of the basic equations of the GSMS model. These macroeconomic constellations show up (see table 1 in the appendix) as shifts of the natural and cyclical productions functions along with macroeconomic liquidity and the other variables. This way, the GSMS model serves to identify specific macroeconomic configurations and to orient their analysis. The tables and graphs in the Appendix show the variables of the model in order to analyze the links among the different parts of the macroeconomy.

\section{IV}

\section{BUSINESS CYCLE ANALYSES}

Academic discussion of the Austrian theory of the business cycle has suffered from many misunderstandings and outright false claims (Block and Barnett 2008). More recently, however, serious considerations of the Austrian approach to the business cycle are on the rise (Cachanosky and Salter 2013) along with interest in Austrian economics in general (White 2012). The following graph (figure 2) presents a sequential analysis of the business cycle in the context of the GSMS model that incorporates various crucial components advanced by scholars of the Austrian tradition.

The GSMS model shows that without monetary intervention, increases in productivity would lead to deflationary economic growth (move from point A to B). Such an expansion would come with a higher purchasing power of money. However, when monetary authorities bring about an inflationary boom as they try to 
maintain «price stability» due some explicit or implicit inflation target $(I T)$, they produce an unsustainable expansion. An increase of macroeconomic liquidity $(M L)$ moves economic activity beyond the natural production frontier to point $C$ in figure 2. Economic activity that exceeds the natural level $\left(Q^{\prime}>Q^{*}\right)$ provokes higher degrees of scarcity and as consequence prices will rise in line with the availability of macroeconomic liquidity.

In due course, the cyclical production frontier, which otherwise would have fallen, moves back in direction towards its original position $\left(C P F^{*}\right)$. At this stage, the hidden monetary inflation turns into open price inflation when the economy moves towards stagflation at point D in figure 2.

The inflationary boom that has turned into a bust comes with an overhang of bad debt. When central banks try to re-inflate in the face of the deflationary contraction of liquidity, they actually commit the error again that marked the inception of the cycle. Warding off beneficial productivity-led deflationary economic

FIGURE 2

GS/MS MODEL OF THE BUSINESS CYCLE

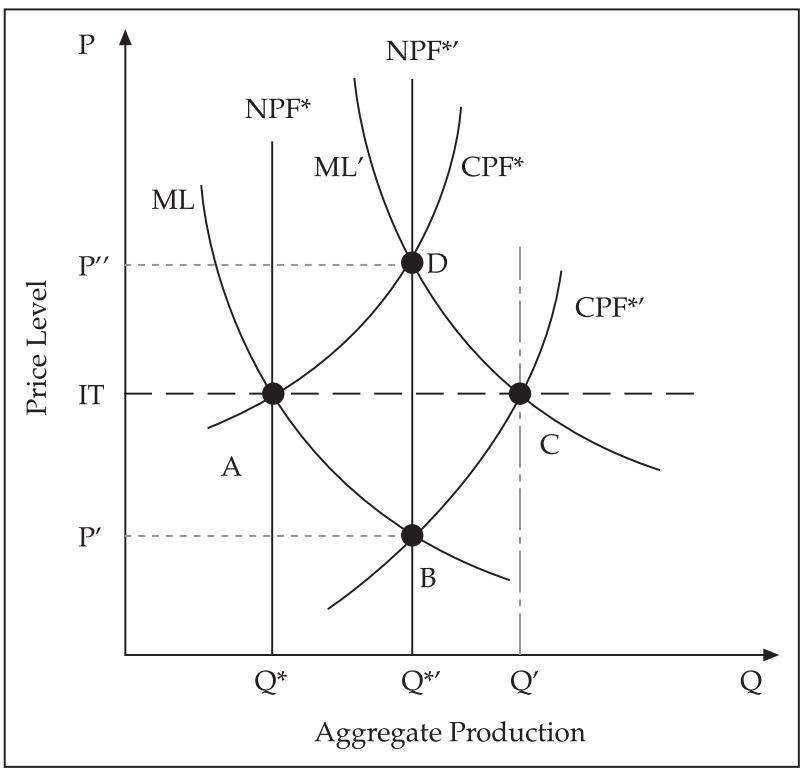


growth instigated the inflationary boom (move from $\mathrm{A}$ to $\mathrm{C}$ in figure 2). Now, when the bust has come, monetary policy confronts malicious deflation as a contraction of liquidity and not due to productivity gains. Things get worse in the bust, when monetary authorities hamper the swift elimination of the recession by endeavors to re-inflate the economy. This way, they make the economy to remain stuck in deflationary depression after the return to point A figure 2 to where it had moved back to in the completion of the inflation/deflation cycle.

\section{$\mathrm{V}$ \\ ECONOMIC GROWTH}

\section{Sustainable economic growth}

In terms of the GSMS model, «natural economic growth» represents the dynamic equilibrium of the system. Productivity-led deflationary economic growth develops in a slow manner and allows the continuous adaptation of expectations. Deflationary interest rate shocks will not emerge when deflation comes from the goods side due to productivity gains. In contrast to this «beneficial deflation», a «malicious deflation» represents a slide into a deflationary depression as consequence of a preceding inflationary boom that typically takes place as a collapse of macroeconomic liquidity. Compressed in a short time span, such and unexpected collapse of liquidity disrupts economic contracts in nominal terms and leaves no sufficient time for revision.

The graph below (figure 3) connects the GSMS model with the standard Solow economic growth model (Solow 1987).

Economic progress lift the production function and accordingly the savings-curve to a level that is in concordance with the higher requirement of capital maintenance. When monetary conditions remain steady, economic growth comes along with price deflation. The cyclical production frontier moves lower, while the natural production frontier moves to the right in the model (figure 3).

The neoclassical economic growth model assumes diminishing marginal returns of capital $(K)$ while the rate of depreciation $(D)$ 
Figure 3

\section{SUSTAINABLE ECONOMIC GROWTH AS PRODUCTIVITY-LED DEFLATIONARY EXPANSION}

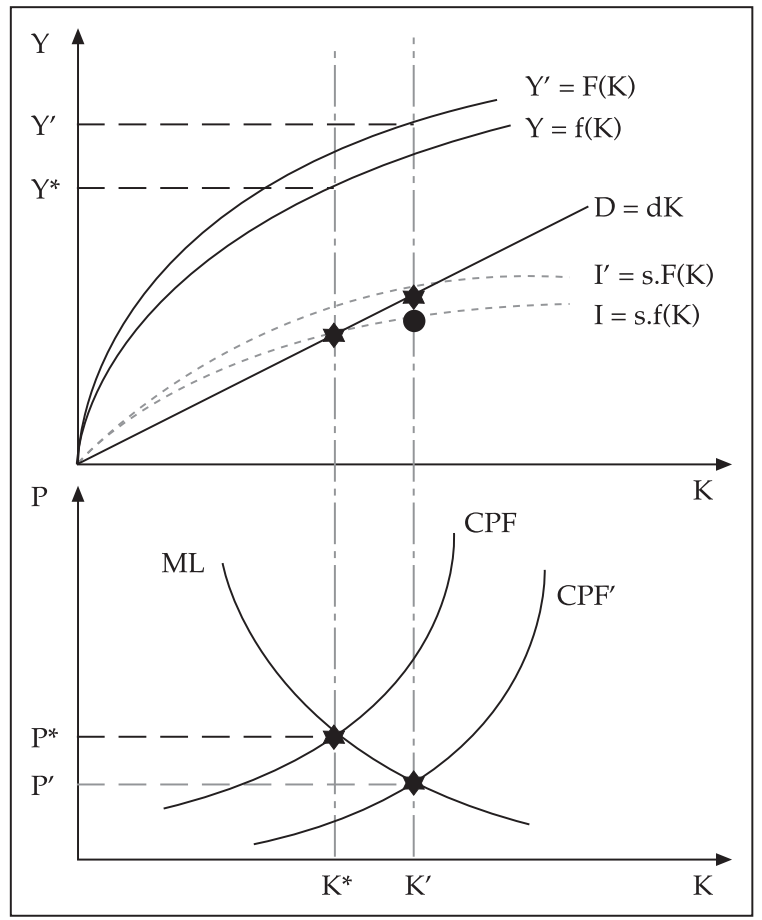

- or rather capital maintenance by the understanding of Austrian economics - is positive-linear $(D=d Y)$. Given an unchanged quantity of labor and absence of technologial progress, income $(Y)$, which in the absence of price changes is equal to the product $(Q)$ becomes a function of capital.

Natural economic growth happens when current consumption is less than production and when savings become investment. Gross investment includes the cost for capital maintenance (depreciation), while net investment consists of a part that represents accumulation of capital (capital enlargement) and the other part that goes into roundaboutness. Roundaboutness extends the capital structure in order to make it more productive. With more roundaboutness, the economy achieves higher 
productivity, which enlarges the potential for further capital accumulation and thus for higher income and more savings. Rising savings permit the maintenance of the higher capital stock. In the Solow-Swan growth model, all savings go into capital maintenance when the economy is at steady state. Roundaboutness, however, means that instead of moving all savings into capital maintenance, part of the savings will go into extending the structure of production. With more economic activity going into "roundaboutness», the maturation period from the inception of the project until it becomes a full-fledged consumption good will rise. This way, roundaboutness depends on time preference, which in turn is a function of currently available funds and of expectations.

In the GSMS model, economic growth is «endogenous» in the sense that it is entrepreneurial decision whether to embark upon higher degrees of roundaboutness. Different from the neoclassical standard growth model, where «innovation» or «technological progress» are exogenous, roundaboutness happens as an extension of the capital structure, which leads to higher productivity and in this sense represents «economic progress».

In a pure market economy, relative prices and the regime of profit and loss will regulate the system whose inter-temporal structure rests on time preference. The degree of time preference defines the division of income between the savings and consumption share and as such, time preference determines the natural interest rate $\left(i_{n}\right)$. This way, the natural interest rate is that interest rate, which reflects time preference and regulates the relative shares of savings and consumption of income. By way of the natural interest rate, time preference determines the appropriate degrees of roundaboutness.

\section{Unsustainable economic growth}

When monetary authorities manipulate the nominal (monetary) interest rate ( $i$ ) with the aim to stimulate economic expansion, they fabricate a deviation from the natural rate and deceive economic actors about the prevailing time preference and about the sustainable degrees of roundaboutness (figure 4). 
FIGURE 4

UNSUSTAINABLE ECONOMIC GROWTH

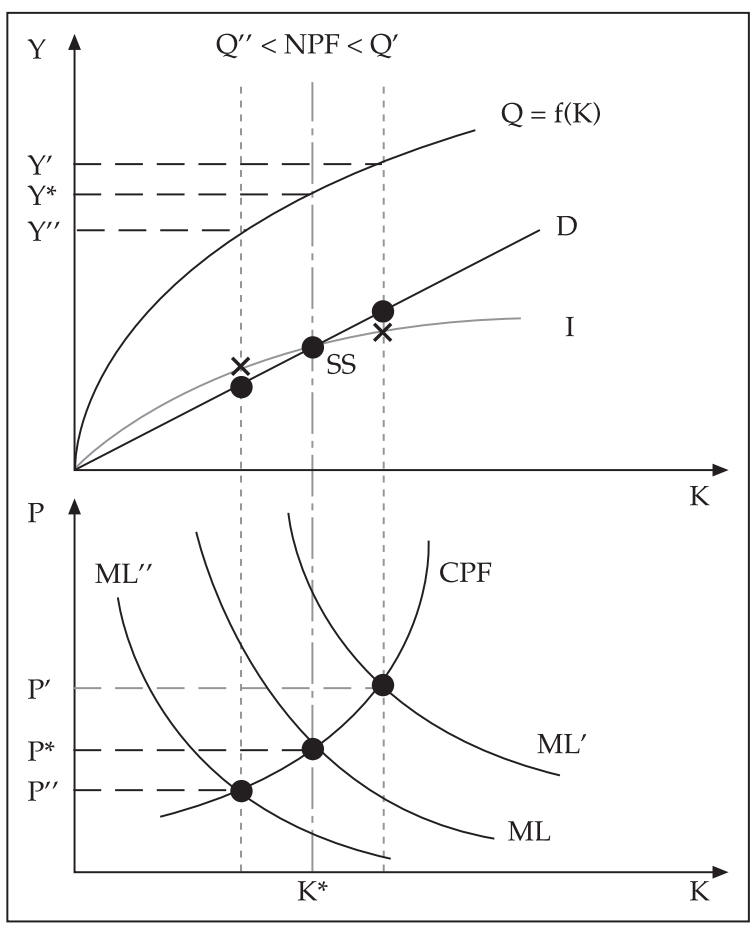

A monetary expansion, wich shifts the curve of macroeconomic liquidity from ML to ML' moves real economic activity from $\mathrm{Q}^{*}$ to $\mathrm{Q}^{\prime}$ beyond the natural output level $\left(\mathrm{Q}^{*} / \mathrm{K}^{*}\right)$, which determines steady state (SS) in the neoclassical growth model (upper part of figure 4$)$. While at steady state, investment $(I)$ is equal to depreciation $(D)$, at points to the right of this equilibirum, depreciation exceeds investment because of the lack of sufficient savings $(D>S)$ Consequently necessary investments $\left(I^{\prime}\right)$ for capital maintenance cannot be achieved. When depreciation exceeds gross investment, net capital formation becomes negative, and the economy will move back to the original equilibirum.

This way, the GSMS-SS model reveals that economic stimulus policies must be judged as to whether they are supportive or detrimental to these factors that can counteract the diminishing 
returns of capital. Deficit spending of government expenditures, for example, does not qualify as a means towards sustainable economic growth because instead of increasing the savings rate, the macroeconomic savings rate would fall with more debt as consequence of deficit spending.

In the GSMS-SS version of themodel (figure 4), deficit spending would at first expand the economy beyond the point of steady state and produce an unsustainable inflationary boom. As consequence, the costs of capital maintenance (depreciation) exceed savings. The expansion will revert. However, the end of the boom would not just move the economy back to the earlier equilibrium, but to a lower level because, ceteris paribus, deficit spending has diminshed the savings rate. Instead of producing economic growth, the policy of deficit spending has led to fall of economic activity below the output level at the inception of the inflationary boom.

\section{VI \\ CONCLUSION}

The GSMS model provides a powerful tool of macroeconomic analysis that avoids many of the ambiguities of the standard ISLM-AS model. The GSMS analysis differentiates systematically between expenditures that go into prices and that part, which goes into real production. Concerning macroeconomic policy, the model is non-interventionist. By letting beneficial deflation happen, malicious deflation will not show up. The GSMS model thus highlights the quintessence of the Austrian business cycle theory according to which inflationary economic expansions are the result of monetary stimuli (which includes public deficit spending) that provoke unsustainable booms that revert into busts. While expansionary policy measures function to initiate a boom, they are ineffective in the bust as the deflationary depression is the direct consequence of the earlier inflationary boom and the economy suffers from an overhang of bad debts as the result of misdirected investments. Modern monetary policy fails to differentiate between beneficial deflation as the result of productivity gains and malicious deflation, 
which comes in the wake of an artificial boom that results in a bust and shows up as contraction of macroeconomic liquidity. In its expanded version as GSMS-SS, the model shows that the natural way of economic progress consists in productivity-led deflationary economic growth.

\section{BIBLIOGRAPHICAL REFERENCES}

Block, W. and BARnETT, W. (2008): Tyler Cowen on Austrian Business Cycle Theory. A Critique. New Perspectives on Political Economy. Volume 2, Number 2, 2006, pp. 26-85.

BoetTKE, P. (2012): The Elgar Companion to Austrian Economics. Edward Elgar Publishing: Cheltenham.

Cachanosky, N. and Willam, A. (2013): The View from Vienna. An Analysis of the Renewed Interest in the Mises Hayek Theory of the Business Cycle (December 4, 2013). Available at SSRN: http:/ /dx.doi.org/10.2139/ssrn.2363560.

Colander, D. (1995): «The Stories We Tell. A Reconsideration of AS / AD Analysis». Journal of Economic Perspectives. Volume 9, Number 3. Summer 1995. Pp. 169-188.

Copernicus, N. (1526): Monetaecudendae ratio. Memorandum to Prussian Diet (http://www.intratext.com/IXT/LAT0488/).

Evans, A.J. and Thorpe, R. (2013): «The (quantity) theory of money and credit», Review of Austrian Economics, Vol. 26, N. 4, pp. 463481.

Fisher, I., with Brown, H.G. (1911): The Purchasing Power of Money. New York: Macmillan. Reprinted in The Works of Irving Fisher (Fisher 1997), Vol. 4.

FRIEDMAN, M. (1956): The quantity theory of money - a restatement, in Friedman M. (ed.) Studies in the Quantity Theory of Money, Chicago, University of Chicago Press.

GARRISON, R. (2000): Time and Money. The Macroeconomics of Capital Structure. Routledge Foundations of the Market Economy. London: Routledge.

HAYEK, F.A. (1975): Price Expectations, Monetary Disturbances and Malinvestments (1933), in: Profits, Interest and Investment and Other Essays on the Theory of Industrial Fluctuations. Clifton, 
N.J. 1975: August M. Kelly Publishers (Reprints of Economic Classics), pp. 135-156.

- (1984): Intertemporal Price Equilibrium and Movement in the Value of Money, in: Money, Capital and Fluctuations. Early Essays. Chicago: The University of Chicago Press, pp. 71-117. Hicks, J. (1980/81): IS-LM: An Explanation. Journal of Post-Keynesian Economics. Vol. III, N.․․ 2, pp. 139-154.

Howden, D. (2013): The Quantity Theory of Money. The Journal of Prices and Markets. Vol. 1, N.o 1, pp. 17-30.

Huerta De Soto, J. (2012): Money, Bank Credit, and Economic Cycles. $3^{\text {rd }}$ edition. Auburn, Ala.: The Ludwig von Mises Institute.

Hume, D. (1752): Of Money, in Essays. London: George Routledge and Sons.

Mises, L. VON (1912/1971): The Theory of Money and Credit. New York. The Foundation for Economic Freedom.

SAlerno, J.T. (1987): The «True Money Supply: A Measure of the Supple of the Medium of Exchange in the U.S. Economy». Austrian Economics Newsletter. 6(4), 1-6.

Solow, R.M. (1987): Growth Theory and After. Prize Lecture for the Sveriges Riksbank Prize in Economic Sciences in Memory of Alfred Nobel. Stockholm 1987.

White, L.H. (2012): The Clash of Economic Ideas: The Great Policy Debates and Experiments of the Last Hundred Years. Cambridge University Press: Cambridge. 


\section{APPENDIX \\ GOODS SIDE/MONEY SIDE (GSMS) MODEL DIDACTIC TOOLKIT}

The tables (table 1 and table 2) provide a sample of typical macroeconomic configurations. One can also capture specific macroeconomic constellations, such as the current Great Recession, which would show up as strong growth of the monetary base, which does not transform into equivalent higher liquidity because of a low banking multiplier and negative velocity. Consequently, the effect of monetary policy on output and prices remains flat.

TABLE 1

THE GS/MS MODEL AS A CLASSIFICATION TOOL OF MACROECONOMIC CONFIGURATIONS

\begin{tabular}{|c|c|c|c|}
\hline & $\begin{array}{l}\text { Macroeconomic } \\
\text { liquidity }(M L)\end{array}$ & $\begin{array}{l}\text { Cyclical production } \\
\text { frontier }(C P F)\end{array}$ & $\begin{array}{l}\text { Natural production } \\
\text { frontier (NPF) }\end{array}$ \\
\hline PLG & 0 & $\searrow$ & $\rightarrow$ \\
\hline MPI & $\nearrow$ & $\uparrow$ & 0 \\
\hline MHI & $\nearrow$ & $\nwarrow$ & $\leftarrow$ \\
\hline MPD & $\swarrow$ & $\downarrow$ & 0 \\
\hline DD & $\swarrow$ & $\swarrow$ & $\leftarrow$ \\
\hline IS & 0 & $\uparrow$ & 0 \\
\hline IB & $\nearrow$ & $\uparrow$ & 0 \\
\hline
\end{tabular}

PLG: Productivity-led (deflationary) economic growth - MPI: Monetary price inflation - MHI: Monetary hyperinflation - MPD: Monetary price deflation - DD: Deflationary depression - IS: Inflationary stagnation (stagflation) - IB - Inflationary boom with g: growth rate $-\mathrm{MB}$ : Monetary base - mb: banking multiplier - V: velocity of circulation -Qc: cyclical production - Qn: natural production $-\pi$ : price inflation rate $-Q$ : Current output - Y: nominal national income. The arrows in table 1 indicate direction of the moves of the curves. 
TABLE 2

MACROECONOMIC CONFIGURATIONS IN TERMS OF THE VARIABLES OF THE GS/MS MODEL

\begin{tabular}{|c|c|c|c|c|c|c|c|c|}
\hline & $g_{M B}$ & $g_{m b}$ & $g_{V}$ & $g_{Q c}$ & $g_{Q n}$ & $\pi$ & $Q$ & $Y$ \\
\hline PLG & 0 & 0 & 0 & + & + & - & + & 0 \\
\hline MPI & + & + & 0 & 0 & 0 & + & 0 & + \\
\hline MHI & + & + & + & - & - & + & - & + \\
\hline MPD & - & - & - & - & 0 & - & - & - \\
\hline DD & - & - & - & - & - & - & - & - \\
\hline IS & 0 & 0 & 0 & - & - & + & - & - \\
\hline IB & + & + & + & + & 0 & + & + & + \\
\hline
\end{tabular}

PLG: Productivity-led (deflationary) economic growth - MPI: Monetary price inflation - MHI: Monetary hyperinflation - MPD: Monetary price deflation - DD: Deflationary depression - IS: Inflationary stagnation (stagflation) - IB - Inflationary boom with g: growth rate $-\mathrm{MB}$ : Monetary base - mb: banking multiplier - V: velocity of circulation - Qc: cyclical production - Qn: natural production $-\pi$ : price inflation rate - Q: Current output - Y: nominal national income. The arrows in table 1 indicate direction of the moves of the curves.

FIGURE A1

STANDARD GOODS SIDE/MONEY SIDE (GS/MS) MODEL

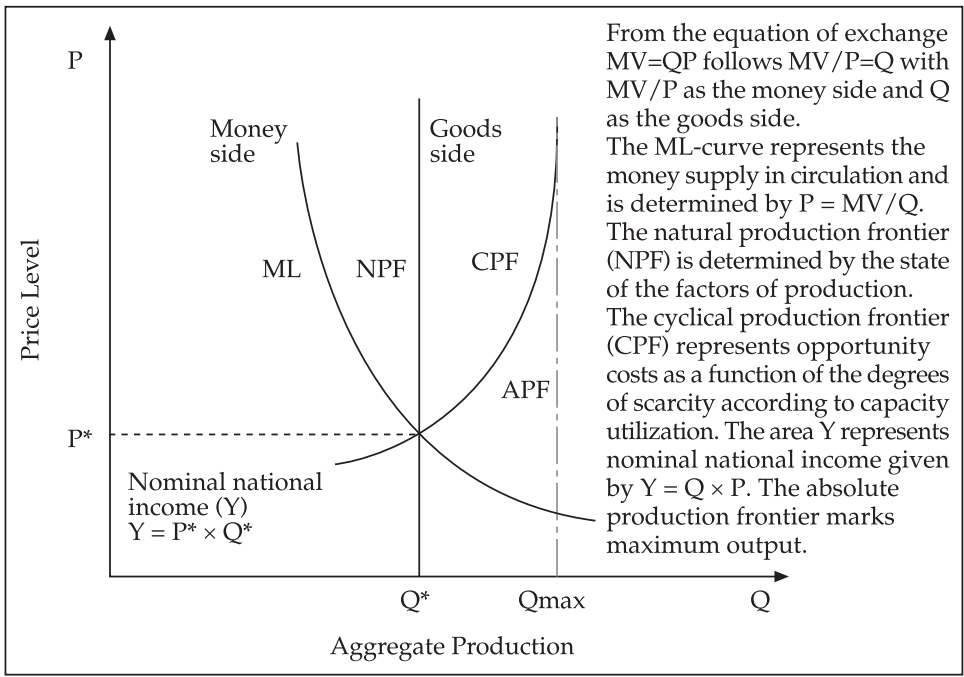

Source: A.P. Mueller, 2014. 
FIgURE A2

PRODUCTION FRONTIERS

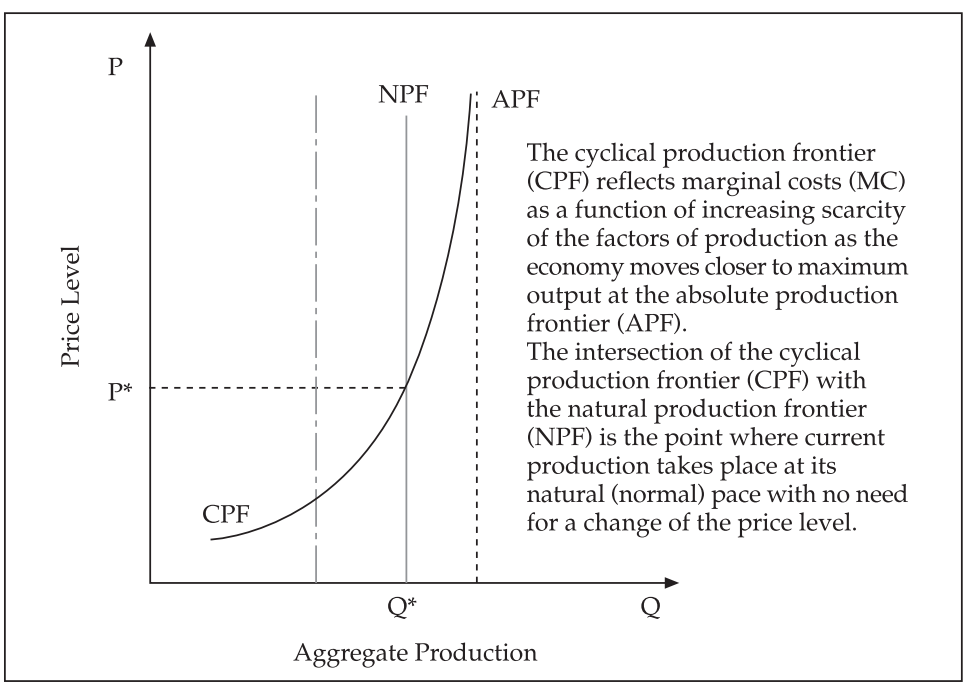

Source: A.P. Mueller, 2014.

Figure A3

\section{MACROECONOMIC LIQUIDITY}

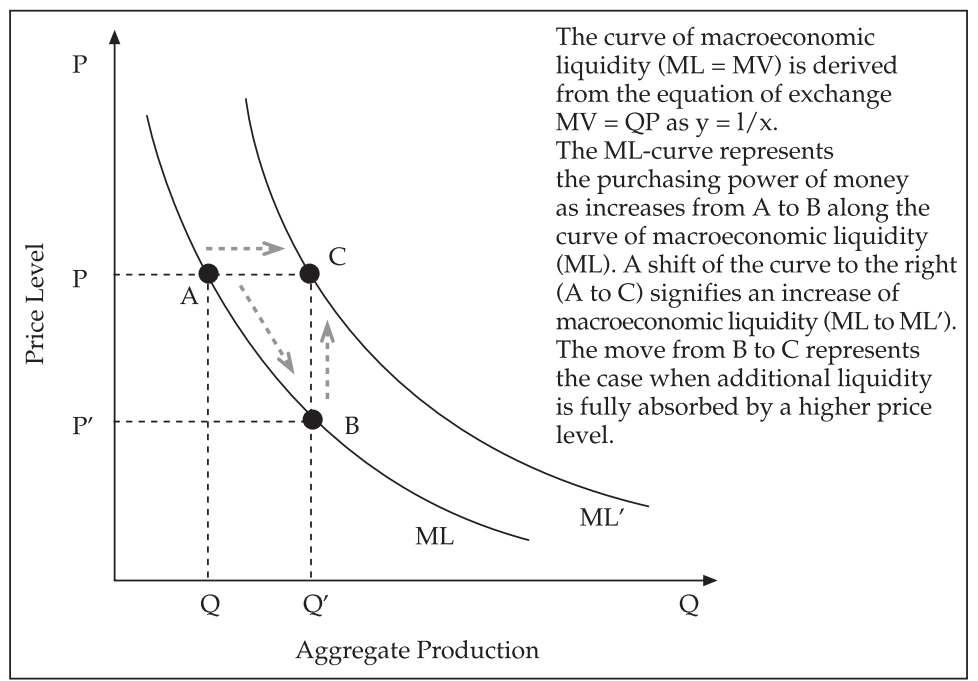

Source: A.P. Mueller, 2014. 
Figure A4

PRODUCTIVITY-LED ECONOMIC GROWTH

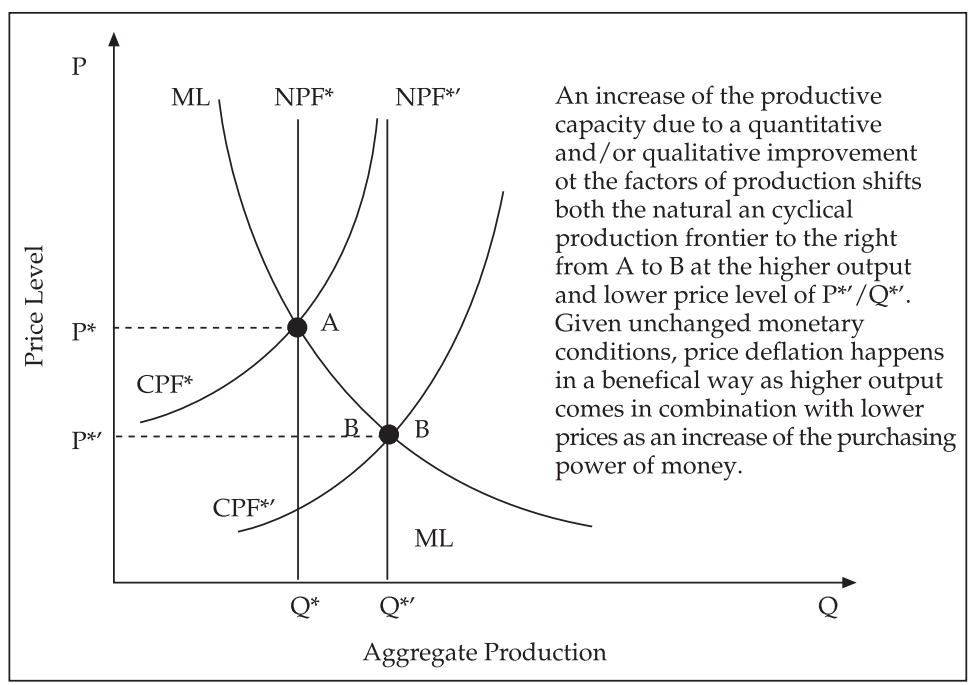

Source: A.P. Mueller, 2014. 
FigURE A5

\section{GS/MS GROWTH EQUILIBRIUM}

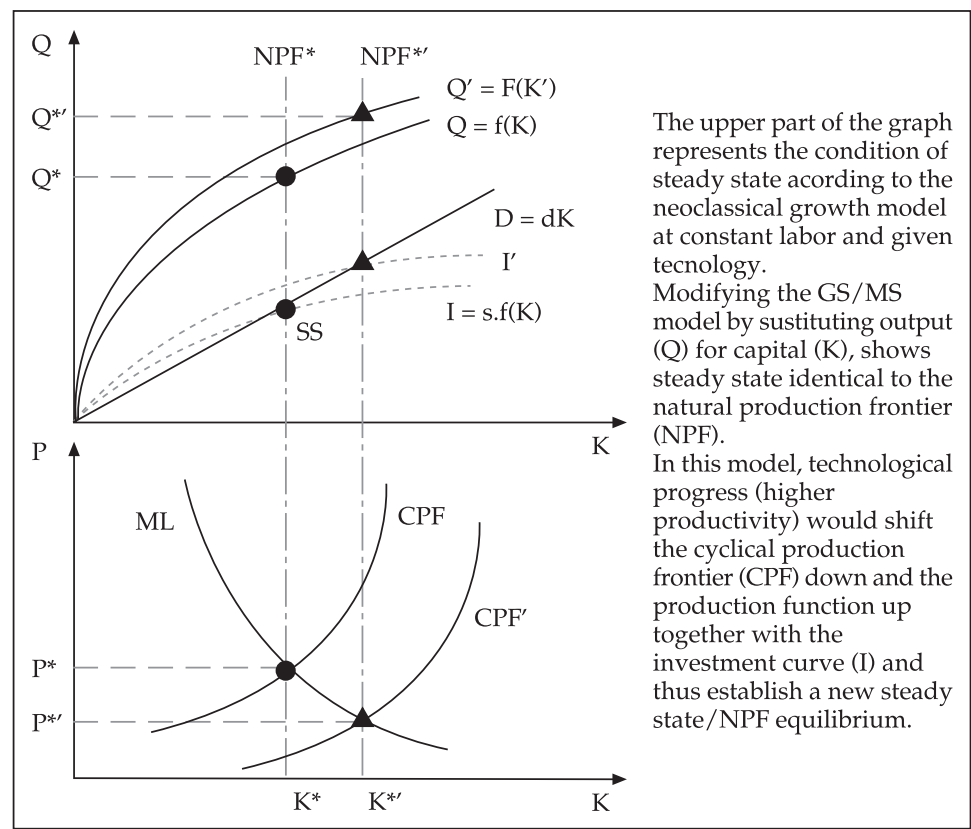

Source: A.P. Mueller, 2014. 
Figure A6

GS/MS MODEL OF THE BUSINESS CYCLE

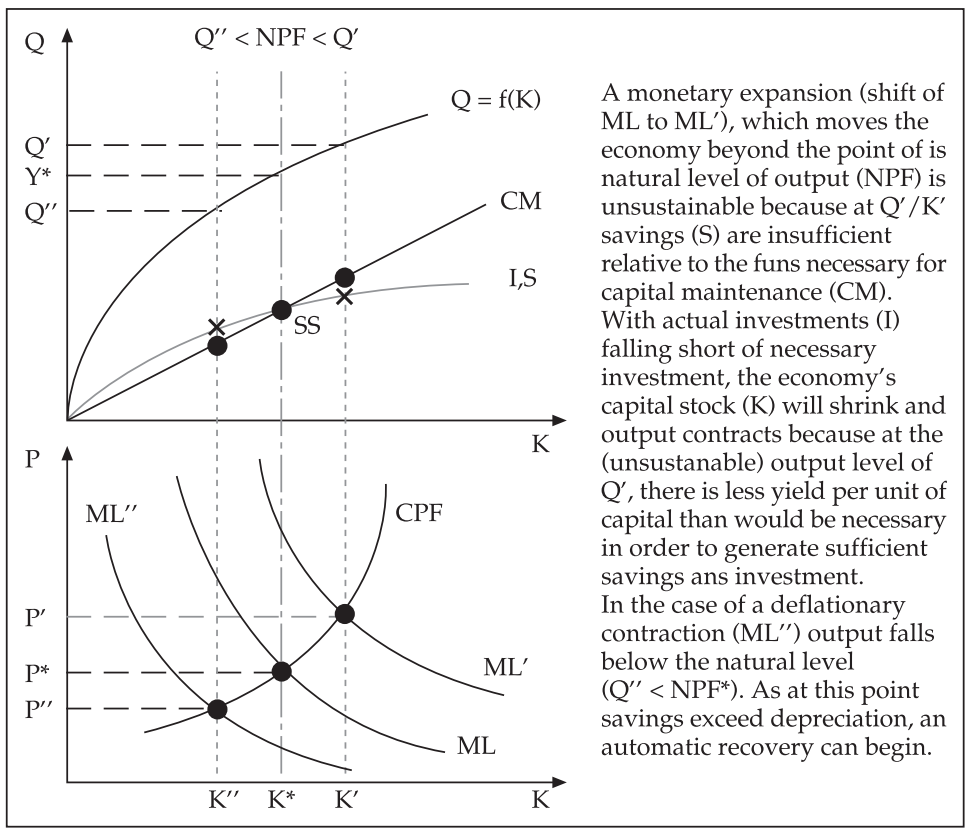

Source: A.P. Mueller, 2014. 
FIGURE A7

\section{ECONOMIC GROWTH DYNAMICS}

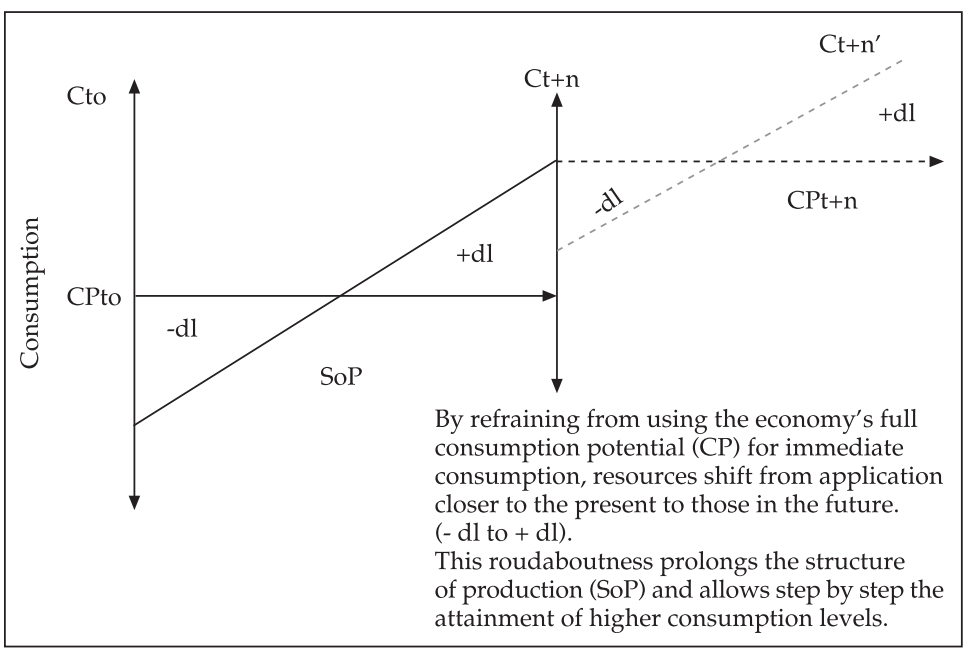

Source: A.P. Mueller, 2014.

Figure A8

\section{MONETARY PRICE INFLATION}

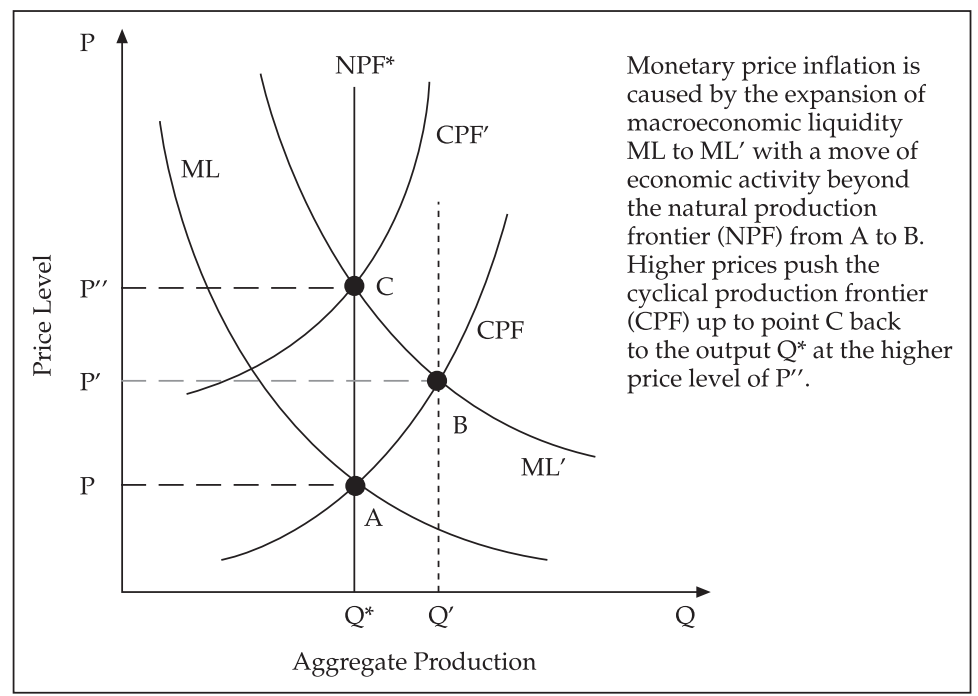

Source: A.P. Mueller, 2014. 
Figure A9

\section{MONETARY PRICE DEFLATION}

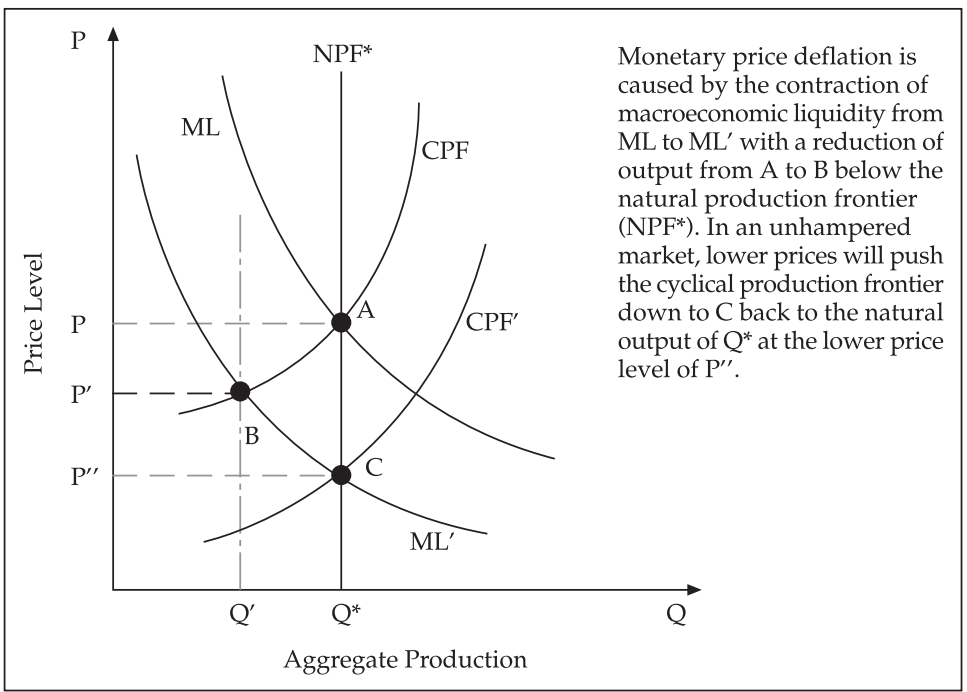

Source: A.P. Mueller, 2014.

Figure A10

STAGFLATION

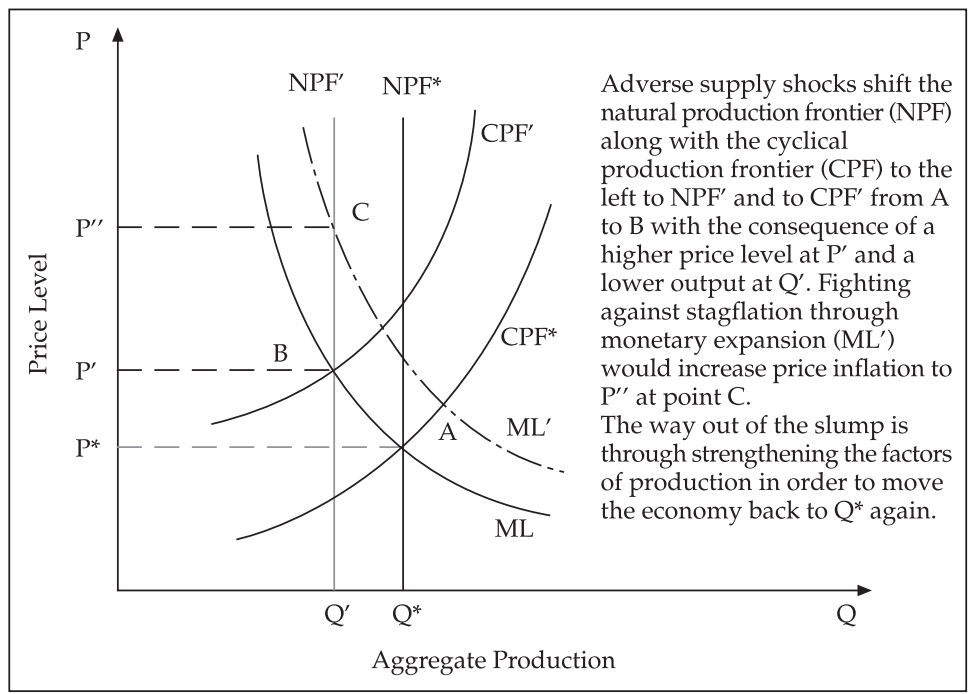

Source: A.P. Mueller, 2014. 
FIGURE A11

STYLIZED INFLATION TARGETING CYCLE

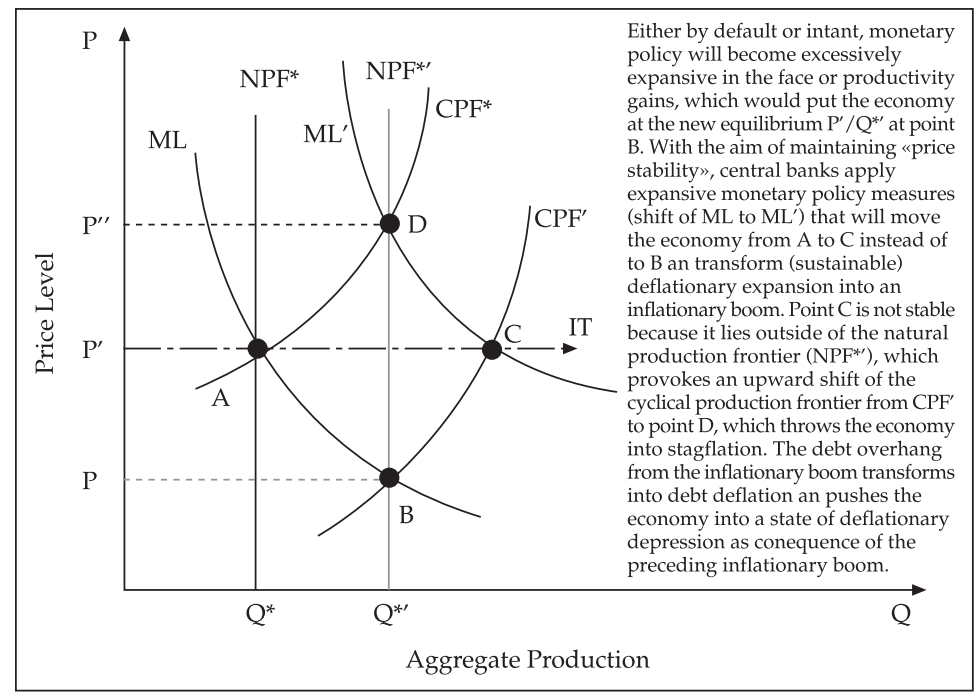

Source: A.P. Mueller, 2014.

Figure A12

NOMINAL INCOME TARGETING

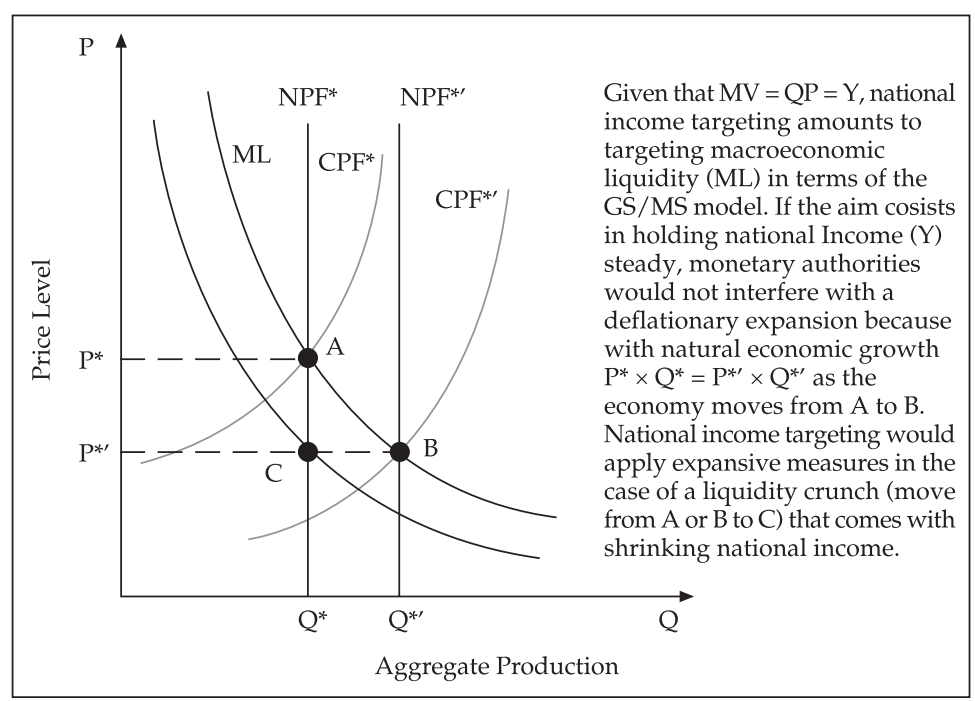

Source: A.P. Mueller, 2014. 
